\title{
Assembling 'indigeneity' through musical practices: translocal circulations, 'tradition', and place in Otavalo (Ecuadorian Andes)
}

\author{
JÉRÉMIE VOIROL
}

Department of Social Anthropology, University of Manchester, Manchester M13 9PL, UK and Graduate Institute of International and Development Studies, Geneva 1211, Switzerland

E-mail: jeremie.voirol@manchester.ac.uk

\begin{abstract}
This article addresses the relation between Andean 'traditional music' and circulations of people, objects, ideas and sounds. Although many studies on Andean indigenous music have explored such circulations, scholars still tend to understand musical practices in terms of 'cultures'. The case of indigenous music from Otavalo, in the Ecuadorian Andes, encourages us to go beyond this approach. I make two arguments. First, by conceiving of the translocal/transnational flows that have shaped 'traditional music' from Otavalo through the concepts of 'network' and 'music world', I unsettle the link - underlying previous approaches - between a specific people, music and place. Second, through the concepts of 'assemblage' and 'mediation', I closely look at processes of 'traditionalisation' and 'indigenisation' to show how, in the context of multiple circulations, social actors nevertheless produce a specific link between people, music and place in order to make a musical practice 'traditional' and/or 'indigenous'.
\end{abstract}

In August 2017, the Metropolitan District of Quito organised, as in previous and subsequent years, the 'Summer of the Arts' (Verano de las Artes Quito). One event in this series was an outdoor music festival in Itchimbía park, close to the colonial centre of the city. On Sunday afternoon, the 'Andean music day' (jornada de música andina), the indigenous band Nanda Mañachi from Otavalo performed live. On stage, nine male musicians wore long braided hair and blue ponchos, white trousers and Borsalino hats. They were accompanied by three female singers, dressed in embroidered white blouses and dark blue anaku (long one-piece dresses), tied with colourful woven belts. They played several pieces, in a lively binary tempo, with different types of cane flutes - rondadores, quenas, zampoñas - as well as bandolines, charangos (two types of small stringed instruments inspired by the guitar), a folkloric harp, violins, acoustic and electric guitars and a bass drum. The strings were sometimes accompanied by the pentatonic melodies of the flutes, sometimes by the women singing in falsetto, while hitting chacchas (a type of rattle made of large seeds). Most of the pieces were sanjuanitos, characterised by repeated melody 
patterns with slight modifications, but some huaynos, for example (a Peruvian genre), were also performed. An enthusiastic audience, made up mainly of white-mestizos from Quito but also of indigenous people from Otavalo and foreign tourists and residents, were enjoying the performance - some clapping their hands, others nodding or moving their body to the rhythm of the music, and some filming with their cell phones. Each piece was followed by a thunder of applause.

In this article, I discuss how to consider and conceptualise circulation in relation to 'traditional', 'Andean' and 'indigenous' music. ${ }^{1}$ As I examine below, on the one hand the Nanda Mañachi performance tends to be watched/listened to as 'traditional', 'Andean' and/or 'indigenous' by a white-mestizo and foreign public as much as by an Otavalo indigenous audience. ${ }^{2}$ On the other, this performance is the result of many translocal circulations of people, objects, ideas and sounds. ${ }^{3}$

In the 1990s, the Andeanist anthropologist Orin Starn sharply criticised the essentialisation in Andean anthropology of indigenous people, who were 'portrayed [...] as outside the flow of modern history' (Starn 1994, p. 18). Following this, Andeanist anthropologists started to think about and integrate transnational and global flows into their work. Studies of Andean music have highlighted several configurations emerging from different kinds of circulations of people, ideas, objects and sounds. In much of their work, there is a tendency to differentiate between the music played in indigenous communities and the derived musical styles that sound 'traditional', 'Andean' and 'indigenous' which are performed on stage - like the performance described above - and often recorded, mainly intended for national and/or international audiences (see particularly Turino 1993, 1998, 2008; Bigenho 2002, 2012; Rios 2008, 2012; Rivera Andía 2018). This differentiation rests on an approach in terms of 'cultures' (what I call the 'culture' lens), which posits the existence of different 'cultures', distinguishable from each other through specific practices, mindsets and values which are seen to be intimately related. Based upon 'culture' as a primordial unit of analysis, the 'culture' lens focuses on how a culture differs from other cultures (minimising similarities) and on internal similarities (downplaying internal differences). From this approach, the musical practices performed in indigenous communities are distinguishable from those of non-indigenous people and embody the indigenous culture and values. The derived styles, inspired by indigenous music, are guided by other values and conceptions, be they white-mestizo or cosmopolitan. The 'properly' indigenous genres are linked to a specific place - the rural communities of the Andes - while the derived styles are associated with highland mestizo-dominated towns and national and international cities. Circulations are more likely to be highlighted in the derived styles than in 'original' indigenous music.

${ }^{1}$ In the Andeanist literature, 'indigenous' music refers to genres originating from the indigenous population; 'traditional' music tends to apply to styles rooted in a (mostly rural) local past; and 'Andean' music refers to genres from the Andean region ('traditional' and 'Andean' music may refer to indigenous or mestizo styles). I build closely upon the meaning that my interlocutors give to these terms, which may be situationally synonymous.

2 The categories of 'indigenous' and 'white-mestizo' are used abundantly in the literature on the Andes. Essentially, they seek to differentiate people who perform, identify, imagine themselves and/or are identified, imagined and ascribed as being from pre-Hispanic origins, from people perceived as 'white' or 'mixed' (particularly from European and native backgrounds): 'mestizo' literally means 'mixed' in Spanish.

3 I use 'translocal' to avoid methodological nationalism, which the term 'transnational' may convey. Indeed, the flows I am interested in are not determined by nation-state borders. Incidentally, 'transnational' is often employed regardless of these nation-state boundaries. 
The Otavalo case allows me to go beyond the 'culture' lens. While most Andeanist studies of music focus on southern Peru and Bolivia, it is important to understand the particularity of Otavalo, which is recognised by Meisch (2002) and Rios (2008, 2012), for example. Otavalo indigenous people have developed a transnational way of life, principally during the second part of the 20th century (e.g. Colloredo-Mansfeld 1999; Meisch 2002), which cannot be separated from their musical practices. As I will describe below, Rios (2012) and Wong Cruz (2012) consider the Andean music performed by Otavalo musicians to be an alteration of traditional music - an alteration which is often referred to as 'folkloric music' while Meisch (2002) qualifies it as 'Andean ethnopop' (because of its many influences of different genres and practices). However, my Otavalo interlocutors consider much of the music to which these scholars refer to be properly 'traditional', 'indigenous' and 'local', generally using the term música tradicional ('traditional music' in Spanish).

In this article, I propose an alternative approach suitable not only for the particular case of Otavalo, but also for other Andean regions, that may help nuance the analyses made from a conception in terms of 'cultures'. On the one hand, I emphasise the translocal flows that produce 'traditional' music and, on the other, I am interested in what counts as 'traditional' and 'indigenous' for the social actors involved in musical practices. Indeed, in most studies of Andean music (but cf. Tucker 2013), it is not always clear who considers (or not) a musical genre or practice to be 'indigenous', 'Andean' or 'traditional': is it the anthropologist or the indigenous and/or non-indigenous people? Therefore, I look closely at processes of 'traditionalisation' and 'indigenisation', namely at what social actors do, how and when, in order to make a musical practice 'traditional' and/or 'indigenous'. What matters in the first place, consequently, is the emic meaning of these terms.

In order to grasp these phenomena of circulations, 'traditionalisation' and 'indigenisation', I propose different theoretical tools, basing my thoughts on the ethnographic case of Otavalo. Firstly, I emphasise the connections and networks of people through the notion of 'art world' (Becker 1982; Crossley \& Bottero 2015). Challenging the precedence of ethnicity/nationality that results from the 'culture' lens, I highlight the category of 'musician' as a relevant category for musicians' self-identification, as it allows me to deploy the Otavalo music network beyond a local place and to show what is at stake in this network. Secondly, the notions of 'assemblage' and 'mediation' (Hennion 1993, 2015; Latour 2005; Mueller 2016; Tucker 2016) help me to apprehend the processes of 'traditionalisation' and 'indigenisation'. How are elements or 'mediators' assembled to signify and materialise 'indigeneity' and 'tradition'?

Starting from circulations (rather than from a specific local space), the approach I develop allows us to rethink 'place', to which 'culture' (according to the 'culture' lens) and 'tradition' (for those engaged in processes of traditionalisation) are closely related. Place is not a given, and should not be taken for granted (see Dorr 2018 for Andean music). Locality must be produced, and this production is carried out through circulations, which are constitutive of a place. Furthermore, locality always refers to other times (the 'culture' lens has long claimed reference to local pasts), but also to other places, making a locale 'dislocated' (Latour 2005, pp. 46, 193-9; Mueller 2016, pp. 103, 110; see also Luvaas 2009). Although some of the dynamics of Otavalo 'traditional music' are very similar to the processes related to 'popular music', as will become clear, their purpose is to produce an idea of 'tradition' related to a place identifiable with indigeneity. 


\section{Andean indigenous music: from the native community to the cosmopolitan city}

In this section, I will examine how some Andeanist scholars deal with flows and circulations - including transnational ones - in their research on indigenous music. Most Andeanist anthropologists have concentrated their research in the Bolivian and central/southern Peruvian Andes; less work has been done in Andean regions of other countries, such as Ecuador or Argentina. My case study focuses on the region of Otavalo in the Ecuadorian Andes, located less than $100 \mathrm{~km}$ north of Quito. It consists of a rural area, mainly inhabited by Kichwa-speaking indigenous people, and the town of Otavalo. This urban centre of approximately 45,000 inhabitants comprises mostly white-mestizos, people who do not recognise themselves as indigenous. ${ }^{4}$ The two administrative entities in which the majority of Otavalo indigenous people live, the cantons of Otavalo and Cotacachi, have a population of about 150,000 inhabitants in an area of $2,300 \mathrm{~km}^{2}$. The indigenous people of the region self-identify and are identified by others as 'indigenous' (indígena in Spanish and runa in Kichwa), but also, to a lesser extent, as 'Otavaleño' or 'Otavalo'.$^{5}$

In the past three decades, and owing to the increase in transnational flows, Andeanist anthropologists have begun to address various kinds of circulations. Scholars have highlighted several different configurations of Andean music practices that have emerged from these circulations. Following most of these researchers, one configuration - namely a specific stabilised way of making music - is situated in rural indigenous communities and has its roots in the pre-Hispanic period. These properly 'local' musical practices constitute, directly or not (from actual encounters to imagination), the model for the other configurations, which depend on the respective roles of different kinds of people, object, idea and sound circulations. Firstly, I describe how many scholars conceive of the music performed within rural indigenous communities. Secondly, I portray some configurations that are thought of as derived from the community music-making and that are performed mostly by nonindigenous people in national towns and cities, and abroad.

The distinctiveness of the music performed within rural indigenous communities includes the use of flutes of pre-Hispanic origin, the privileging of high-pitched sounds, the particular structure of the pieces, performances during local festivities where the public participates through dancing, specific ways of playing the instruments, and so on (see Turino 1993, 1998, 2008; Bigenho 2002; Stobart 2006, 2008; Tucker 2016; Rivera Andía 2018). Community musical performances are often associated with specific cultural values (such as reciprocity, egalitarianism or a particular aesthetic) and with particular symbolisms and cosmological aspects (e.g. Turino 1993, 1998, 2008; Stobart 2006, 2008; Rios 2012; Rivera Andía 2018). These considerations convey an image of this music as part of a specific 'culture', situated in the Andean countryside and distinctive from 'other cultures', mainly those of whitemestizo and 'Western' people.

4 The category of 'white-mestizo' is not a self-identification category: it comes from the social scientific literature on Latin America (see footnote 2). Otavalo indigenous people label the members of this group as 'mestizo' in Spanish or 'mishu' in Kichwa.

5 The category 'Otavalo' is principally used by indigenous leaders and intellectuals. The Ecuadorian state recognises indigenous people from Otavalo as being from the 'Kichwa nationality' and from the 'Otavalo people', who are a component of the 'Kichwa nationality'. 
However, scholars also mention cases in which mestizo (instrumental, stylistic, aesthetic and/or conceptual) influences have been incorporated into local indigenous music. Some 20th century examples include the reappropriation of Bolivian mestizo sikureada (played with panpipes of pre-Hispanic origin) by indigenous communities in different parts of Bolivia and southern Peru (see Turino 1993; Stobart 2006; Rios 2012) and the integration of string instruments (of Spanish origin) into the annual cycle of local rituals by indigenous people from Northern Potosí, Bolivia (Stobart 2006). These few elements give an idea of the exchanges and circulations that may happen between rural-indigenous and urban-mestizo people in the development of local musical practices.

The kind of musical practices performed in rural indigenous areas is conceptualised by Turino (2008, p. 21) as 'participatory music', which he contrasts with 'presentational music'. The former configuration is performed in a way that encourages people to participate through music-making and/or dancing, while the latter establishes a clear separation between the musicians (performing) and the audience (listening and watching) (see also Rios 2012).

As widely mentioned in the literature, the indigenismo ideology is an important phenomenon concerning the evolution of Andean music, notably towards presentational performances. This ideology emerged in Latin America at the beginning of the 20th century in academic and artistic urban white-mestizo milieus, and aimed to tackle the dire economic and political situation of indigenous people and to revalorise some of their cultural expressions, particularly music and dance (for Peru, see Turino 1993; De la Cadena 2000; Tucker 2013; for Bolivia, see Bigenho 2002; Canessa 2006; for Otavalo, see Huarcaya 2014). The indigenismo ideology sought to include indigenous people, who were otherwise marginalised, in the concept of the nation. However, indigenous people were generally not involved in the indigenista intellectuals' reflections, activities and musical, dance and theatrical performances which were meant to represent indigenous 'culture', ${ }^{6}$ as most scholars have emphasised (for a more nuanced position cf. Mendoza 2008). Indigenismo, therefore, generated contacts and circulations, which had an effect on the sound and performance of the music conceived of as traditional. Those engaged in this process sought to adapt indigenous music and to make it accessible for a national and international public.

Turino (1993, chap. 5), for example, shows the role of an indigenista mestizo in the 1920s in a rural district in southern Peru in the formation of an ensemble of indigenous people, which played local panpipes for regional and national urban white-mestizo publics. Tucker $(2013,2016)$ discusses the evolution from the 1970 s of the chimaycha, an indigenous 'traditional' style from a rural area of Ayacucho, Peru, which is shaped, among other factors, by indigenista mestizo academics, as well as media and technology, moving also from participatory to presentational performance. ${ }^{7}$ In Bolivia, Bigenho $(2002,2012)$ is interested in different groups of white-mestizo musicians playing genres inspired by indigenista conceptions. As

${ }^{6}$ The development of the notion of 'culture' in indigenista thought was also a way to dismiss the conception of 'race'; however, racial considerations have persisted in many underlying ways (De la Cadena 2000).

7 The work of Tucker (e.g. 2013, 2016), as well as the recent research of Stobart (e.g. 2011, 2017), focus on the role of media and technology in the creation and production of music by indigenous artists. These important topics have particularly drawn the attention of scholars working on Andean-inspired popular 
from the 1980s nationalist narratives began to distance themselves from the idea of a homogenous nation, this music has become an emblem of a multicultural Bolivia for national audiences and of a united nation for international publics, for whom this country equates to indigeneity (Bigenho 2002). Furthermore, Bigenho not only highlights the role of white-mestizo people in the shaping of this Bolivian Andean music, she also emphasises the influences and implications of different European and Japanese musicians, particularly from the 1960s (Bigenho 2012).

As several scholars have noted (Turino 1998, 2008; Bigenho 2002, 2012; Rios 2008, 2012; Dorr 2018; Rivera Andía 2018), a music acknowledged as 'Andean' has become recognised internationally. Rios (2008) shows how Andean music became famous in Europe, where Paris played a central role, through Latin-American nonindigenous and non-Andean musicians, particularly from Buenos Aires. These artists created a standardised ensemble, named 'Andean conjunto' by Rios (2008, 2012), which combines distinct types of instruments (particularly quena, zampoña, charango, guitar and bombo, which are rarely played together in the rural Andes) ${ }^{8}$ and plays a repertoire often referred to as 'Andean folkloric music' by scholars (e.g. Rios 2008; Turino 2008; Bigenho 2012). This repertoire comprises tunes of genres from a range of Andean regions and beyond (including mestizo genres from Venezuela and Chile, for example). In doing so, these musicians tried to include musical variety and to produce a cleaner style (in terms of voice and instrumental harmony, melody and timbre) in order to reach the European public. From the 1970s, Chilean leftist musicians, fleeing the Pinochet right-wing dictatorship, contributed to politicising and spreading this style worldwide (associating it with social resistance), while benefiting from an already well-established market (Rios 2008; Dorr 2018). Mainly from the 1980s, mestizo groups from the Andes, like Bolivia Manta (see below), tried their luck travelling to Europe to perform alongside mostly Argentine and Chilean bands (Rios 2008; see Bigenho 2002, 2012). Some Chilean refugees in Ecuador also created their own Andean conjuntos in the 1970s, which inspired some Ecuadorian middle-class university students to form similar ensembles (Wong Cruz 2012, pp. 194-5).

The circulation of people, ideas, sounds and objects as described above has been part of the process of 'globally circulating imaginings of an Andean world' (Bigenho 2012, p. 9; see also Dorr 2018). The international success of Andean folkloric music must also be related to the spread and commercialisation of 'world music', owing to the commodification of otherness and exoticism for North American and European audiences (see Erlmann 1996; Feld 2004; Stokes 2004; Rios 2012; Dorr 2018).

\section{The 'culture' lens and Otavalo music}

Specialists in Andean music have described numerous circulations of people (from different 'ethnic' and national backgrounds), ideas (indigenismo, multiculturalism, views about 'authenticity', among others), sounds and objects (instruments, technologies). Their studies have allowed us to understand many dynamics of the processes of constitution and evolution of Andean music styles and belongings. These

music (such as chicha, tecnocumbia, etc.) not generally considered as traditional; however, this body of literature is beyond the scope of this article.

8 The quena is a straight end-notched flute, the zampoña is a double-row panpipe, the charango is a small stringed instrument inspired by the guitar and the bombo is a large double-headed drum (Turino 2008). 
processes of flows coincide with the ever-increasing access to technology, the commodification of music and exoticism - processes already well acknowledged concerning popular and national musics in Latin America (e.g. Wade 2008) - and also with attempts to include indigenous people in the nation, whether through indigenismo or multiculturalism.

The scholars considered above have tended to conceptualise and to grasp the dynamism and the circulations they have stressed through the 'culture' lens: namely, that the musical practices in Andean rural communities embody values identifiable with an indigenous 'culture' (recognised as changing over time), such as 'egalitarianism' and 'communitarianism' (Turino 1993, 1998, 2008; Rios 2012; Stobart 2006, 2008; see also Bigenho 2002). ${ }^{9}$ The privileged performance is participatory, which is intimately linked to the values mentioned; this conveys a sense of 'culture' as a totality. This music-making is distinguishable from the other 'Andean-sounding' musical styles characterised by a presentational performance, which equates to white-mestizo and/or Western 'cultures' and values. This kind of performance is guided by individualism, professionalism and hierarchy, among others (Turino 1993, 2008; Rios 2012): as a result, soloists and a 'good quality of sound' are valued over good 'quality of social participation' (Turino 1993, p. 129). The impact of white-mestizo and urban conceptions on the performances and sound of indigenous ensembles playing nationwide or of indigenous migrant bands in Lima makes their music only partially indigenous, according to Turino (1993, 2008): their 'harmonic' and 'polished' style, the hierarchised organisation of music-making and of the groups' members are aspects that differentiate it from the community music. Therefore the 'culture' lens conveys the idea, explicitly or implicitly, that there is a core of musical practices, situated in rural indigenous communities, which are transformed when people and/or practices leave these spaces. Thus, the transformed musical practices lose fundamental aspects of their 'cultural' indigenous quality. The 'culture' lens approach, consequently, tends to reproduce the link between people-culture-place: indigenous people, their music and 'culture' are located in the countryside.

The case of Otavalo, on the contrary, paints another picture, and its specificity encourages us to move beyond this theoretical model. Firstly, the region of Otavalo is clearly decentred compared with the geographical focus of most studies on music in the Andes (situated, as I noted, in Bolivia and central/southern Peru). Secondly, as handicraft production and its commercialisation replaced agriculture as the main activities during the 20th century (Colloredo-Mansfeld 1999), many Otavalos have travelled, from the 1940s onwards, within Ecuador and South America, then to Central and North America, Europe and Japan, in order to sell their products (Colloredo-Mansfeld 1999; Meisch 2002). These aspects have had an impact on Otavalos' musical practices.

Interestingly, Rios (2012, pp. 14-15) notes that Andean conjunto has influenced the indigenous music of the Andean regions of northern Peru and Ecuador, notably of Otavalo, while having no impact on indigenous music from southern Peru and Bolivia. Meisch (2002), whose work deals with the multiple flows impacting Otavalo music from the 1970s, highlights the influences of Andean Peruvian and

\footnotetext{
9 In this article, 'culture' refers specifically to the holistic notion as developed in anthropology: namely, that the different domains of life are closely related, particularly by the same values, which makes one culture different from another. A non-holistic conceptualisation of this notion may be more relevant in other social sciences and humanities disciplines.
} 
Bolivian 'folkloric' bands, and also of transnational genres like rock, reggae, cumbia and pop, among others. Much like Wong Cruz (2012, pp. 160-61, 214), who considers Otavalo bands like Nanda Mañachi to be 'folkloric music' (as opposed to 'traditional'), Rios's and Meisch's stances evoke a detachment and an alteration of traditional music in Otavalo music, which would implicitly lose its indigeneity. Indeed, Meisch concludes that Otavalo musicians have become part of the world beat or global ethnopop music scene' (2002, p. 179) and that the 'result is a pastiche of musical and cultural influences, cross-currents, and identity constructions that can only be called postmodern (or perhaps confused)' (2002, p. 189). To nuance these viewpoints, I address how Otavalo and non-indigenous people understand Otavalo music. In doing so, I do not temper the multiplicity of translocal flows: on the contrary, I want to emphasise them, thus proposing an alternative to the 'culture' lens that rests on and starts from flows, rather than bounded places.

\section{The constitution of Otavalo traditional music through circulations}

Based on the discussion above, it is not surprising that the performance of Nanda Mañachi in Quito, described at the beginning of this text, is conceived of as 'traditional', 'Andean' and 'indigenous' by the white-mestizo and foreign audience. However, indigenous people from Otavalo perceive this band in the same terms. They even consider them to be one of the most representative groups of Otavalo traditional music. The sound (which may remind some older Otavalo people of the music played in the 1960s and 1970s at certain festivities), the materiality and visuality of most of the instruments and the dress of the performers evoke their 'own tradition' for Otavalo people. In my conversations with them, they referred to this music mostly as 'traditional music', but also 'our music', 'music from here' and 'local Andean music'. As I will show now, Nanda Mañachi's performance is in fact the result of many translocal flows. ${ }^{10}$

Nanda Mañachi was formed in 1969 by Thibaut, ${ }^{11}$ a French musicologist married to an Otavalo woman, who selected amateur musicians and singers from communities in the region and beyond. Thibaut named the band 'Nanda Mañachi', borrowing a local expression which literally means 'lend me the path' in Kichwa, an affective phrase used by someone who walks close to the house of an acquaintance. The French musicologist chose mainly sanjuanito tunes to be recorded and performed on stage during the 1970s (an LP was released in 1984: Meisch 2002, p. 140). The sanjuanito genre is associated with the San Juan festival in June, the most well-attended annual festive event celebrated by indigenous people in the Otavalo region. At this festival, informal groups of amateur musicians and dancers - most of them dressed up - visit particular houses in their community and in neighbouring

10 The information I summarise here results mainly from 5 months of ethnographic fieldwork that I carried out for a postdoctoral project at the Department of Social Anthropology of the University of Manchester, funded by the Swiss National Science Foundation. I also use relevant ethnographic data collected in previous fieldwork sessions in the region of Otavalo for my PhD research (equating to 20 months in total). I principally conducted fieldwork in the rural and urban areas of Otavalo, but also in Quito and Ibarra, the provincial capital, with indigenous, white-mestizo and foreign participants. I had numerous informal conversations with musicians, producers and music-lovers, and conducted around 20 semi-structured interviews for my postdoctoral research.

11 All names of my interlocutors given here are pseudonyms. 
villages over several nights (see Meisch 2002; Wibbelsman 2005; Voirol 2013). This participatory music-making, consequently, has been adapted towards presentational performances. It is worth noting that Thibaut organised a tour in France at that time, where the band had some success and won some prizes. Miguel, a professional musician from an Otavalo community, told me: 'Thibaut experimented with getting together with musicians from different areas [of the region], using his European way of thinking to see what happens. Actually, it was a good idea, because there are roots [between these regional areas], then the merger could work'.

The 1970s constituted what Meisch (2002) refers to as a 'musical renaissance' in Otavalo (see also Schechter 1998), as there was an increase in the formation of formal bands that rehearsed and played what they called 'traditional music' (mainly inspired by local sanjuanito). From this time, mestizos from the town of Otavalo began to take an interest in the music played by indigenous people from the nearby rural areas. For example, Diego, the owner of a disc shop in the town, was the first to record Otavalo bands (particularly Indoamérica, remembered as one of the first promoters of traditional music in the region), and some radio stations broadcast indigenous bands performing live. Diego told me that he became interested in indigenous music because he liked how it sounded. It was a time, however, when indigenista ideas were debated in white-mestizo elites in Otavalo (Huarcaya 2014). Consequently, we can imagine that the circulation of these ideas had an impact on Diego's and the radio station owners' tastes and considerations.

The 1970s also saw an important development in the indigenous movements in Ecuador. In addition to their fight for education, justice and access to land, these social movements sought to revalue indigeneity as a legitimate 'identity' and 'culture' (e.g. Pallares 2002; Cervone 2012). As part of this process in Otavalo, indigenous leaders created 'cultural centres' (centros culturales) in the 1970s and 1980s, which encouraged indigenous musicians to carry out research in different communities in order to 'get back' ('recuperar', as my interlocutors said) local tunes. These centres also promoted musical styles identified as 'Andean' from Bolivia, Peru and Chile. The connotations of resistance that this music had acquired internationally (see Rios 2008; Dorr 2018) were in line with the political project of indigenous movements. Additionally, in the 1980s, some indigenous and white-mestizo intellectuals set up peñas ${ }^{12}$ in the town of Otavalo in order to promote Andean music, which generated direct relationships with several groups from other Andean countries (see also Meisch 2002, p. 141). Incidentally, Otavalo musicians started to play the charango and the quena at that time, as these instruments were brought to the area by Peruvian and Bolivian ensembles. Segundo, a former musician, remembered when the Andean music Chilean band Inti Illimani came to play in his community in the mid-1970s, and told me: 'from that moment, young people began to use zampoña panpipes, to play Bolivian music, and so on. First, they looked weird playing these instruments'. This comment shows that instruments - and by extension music genres - which nowadays evoke 'tradition' for most local and non-local people did not have this meaning some decades ago.

12 As defined by Dorr (2018, p. 193), in Latin America, a 'peña is a popular performance venue, often associated with leftist politics, where artists and audiences convene to eat and drink, dance, and engage in political discussion'. 
Bolivia Manta, a band of mestizos from Bolivia, ${ }^{13}$ performed in Otavalo in 1984 and was very successful. They had previously toured with Nanda Mañachi in France. Each band started to play each other's tunes (releasing an album together in 1983; Meisch 2002, p. 140). During a conversation, Miguel contended that: the union with Bolivia Manta gave Ñanda Mañachi a very special colour, it widened its colour palette, they began to play huayno ${ }^{14}$ and so on'. Roberto, an Otavalo musician who is still active and who played with both Nanda Mañachi and Bolivia Manta in the 1980s, affirmed to me that the latter band had been greatly influential in the music played by Otavalos, and he spoke of their music as his 'initiatory path'.

Meisch (2002) argues that the process of 'musical renaissance' in Otavalo was also stimulated by the rise of tourism and craft textile production and trade. The 1990s constituted a boom in seasonal Otavalo migration to Europe (see Colloredo-Mansfeld 1999; Meisch 2002): those who migrated there, generally every year from May to December, sold their handicraft products. Many of these migrants, like Roberto, played music, mainly on the streets, where they also sold their albums, but also at festivals and in schools. The Otavalo musicians benefited from the friendly interest in Andean music. Alfredo, a member of Nanda Mañachi at that time, went to Europe every year with some of his bandmates. He told me that they got to know other artists from Peru and Bolivia there, and learned different Andean styles of music (such as huayno) and instruments (including zampoña panpipes), while at the same time developing their musical skills. Roberto told me that they met also local musicians in Europe.

Therefore, there have been many (sonic, instrumental, conceptual) influences, from many people and places, on the music that a band like Nanda Mañachi plays. Indeed, as Rios (2008, 2012) suggests regarding Otavalo bands, the composition of the group resembles that of the Andean conjunto; Nanda Mañachi plays the staple instruments of Andean conjunto, namely the quena, zampoña, charango, guitar and bombo (Rios 2012, pp. 5-6; see Turino 1998, p. 221); however they also still play the rondador, a local type of cane panpipe (see Figure 1). The group also interprets tunes from other parts of the Andes, of indigenous and mestizo origins. Their music was also shaped by a Frenchman and his views on what indigenous music was or should be. Some of the tunes that they played on stage in Quito in August 2017 were of mestizo Peruvian origin and others came from Otavalo, but some had been arranged by Thibaut. Nevertheless, Ñanda Mañachi was watched and listened to as 'indigenous' and 'local' by the heterogenous audience, and the group perceives itself as such. Therefore, traditional music in Otavalo has evolved in a very dynamic way and is not limited to the community scale. This process is similar to that described by Tucker (2013, p. 335) for the chimaycha (influenced by technology, urban-mestizo huayno, tropical rhythms and electric sounds, among others), as opposed to the music of rural communities described by Turino (1993, 1998), Stobart (2006, 2008), Rios (2012) and Rivera Andía (2018), for example.

Additionally, Otavalo indigenous musicians are active in 'representing' indigeneity and what is 'indigenous' or 'traditional' music. Since the 1970s and the musical renaissance, many indigenous bands have performed locally, nationally and internationally.

13 Incidentally, Boliviamanta means 'from Bolivia' in Kichwa. The group was formed in France in the 1970s. Rios (2012, p. 7) affirms that this band is one of the 'Bolivian urban folkloric ensembles' that 'strive to reproduce accurately the stylistic characteristics of Southern Andean rural indigenous music'.

14 Huayno is a mestizo genre from highland Peru, which has become very popular in this country (see e.g. Turino 2008; Tucker 2013). 


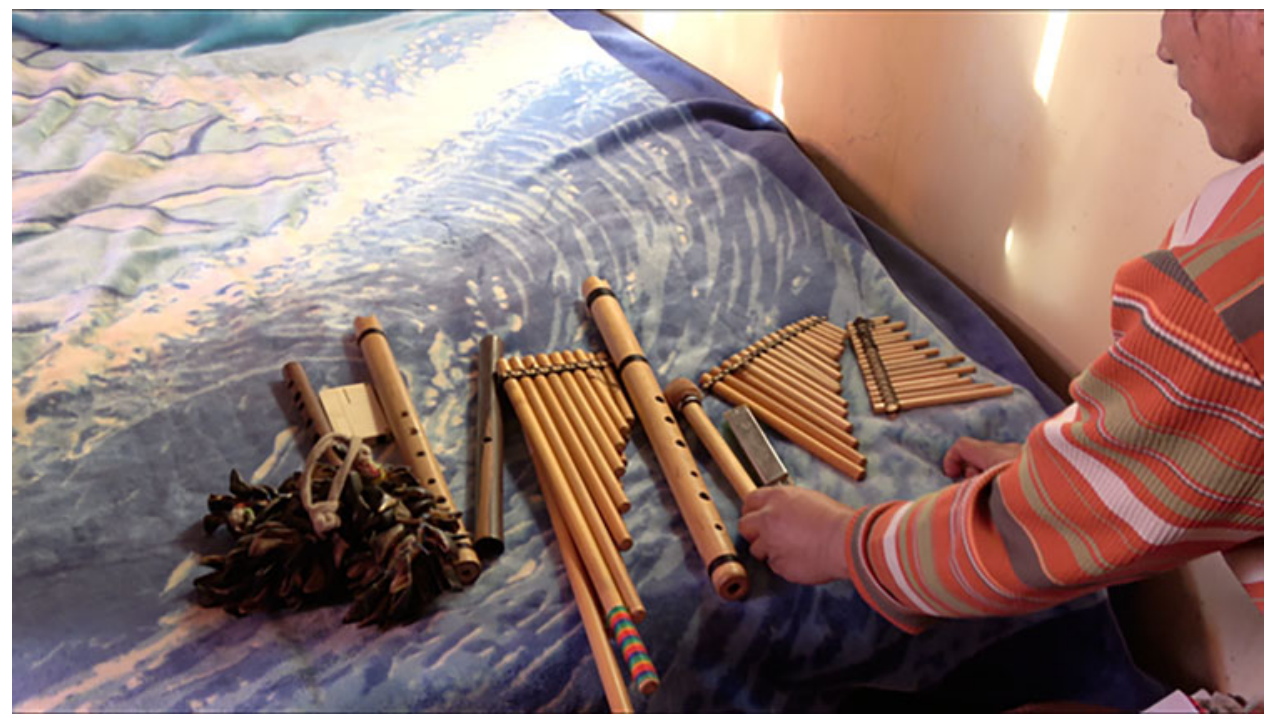

Figure 1. Pablo showing me the range of flutes he plays: non-local quenas and panpipes, and on the extreme right the rondador.

This seems to be a specificity compared with Peru and Bolivia, where most of the bands performing a 'Andean-sounding' music for an (inter)national public are made up of white-mestizo and even foreign people (see Bigenho 2002, 2012; Rios 2008, 2012).

However, non-Otavalo bands have also represented Otavalo traditional music. The most famous and influential is Trencito de los Andes, which is made up of three Italian musicians. Somewhat like the Bolivian mestizo group Música de Maestros, for example (Bigenho 2002), these Italians have, since the 1980s, carried out research in different parts of the Andes in order to compose, play and record tunes. According to Roberto, they perfected Otavalo indigenous music, as it is recognised by many musicians from Otavalo. He added that they constitute 'one of the greatest achievements in Andean music at the scientific level'. Trencito de los Andes have collaborated with local musicians and maintain good relationships with some of them, Roberto included. They have thus had an effect on the sounds considered to be 'traditional' and have had an impact on Otavalo bands: however, the opposite is also true. Otavalo people who listened to the Italian performers may even have mistaken them for Otavalo indigenous musicians, as observed by Meisch (2002, p. 189).

Therefore, as the cases of Ñanda Mañachi and Trencito de los Andes show, Otavalo traditional music results from a transnational process, as circulations of people, sounds, objects and ideas have constituted and shaped it. Dorr (2018) makes a similar argument in a more general way for Andean folkloric music, and Wade (2000, 2005, 2008) for Latin American popular 'national musics', such as the Colombian porro, the Argentine tango or the Brazilian samba.

\section{Beyond the 'culture' lens}

To grasp the Otavalo case in all its particularity and complexity, I argue that we must move beyond the 'culture' lens, which informs much of the analysis of music in the 
Andes. While I describe traditional music in Otavalo as a transnational process, the scholars considered are more likely to highlight transnational flows when they deal with Andean folkloric music and not with indigenous musicians. To analyse these flows, Turino (2003, pp. 61-2) introduced the notion of 'cosmopolitanism': he defines a 'cosmopolitan formation' as a 'cultural group' sharing specific values, aesthetics, practices and conceptions, coming into being through socialisation and not based on heritage and location. Andean folkloric music and its public are part of the 'modernist capitalist' cosmopolitan formation, which is dominant nowadays (Rios 2008, p. 147). The people involved are 'culturally' close, as they share 'modernist values' such as progress, capital accumulation and eclecticism, among others, according to Turino (2008, pp. 127-9; see also Rios 2008). For Turino (2008) and Rios (2008, 2012), this makes their music very different, 'in terms of instrumentation, repertory, aesthetics, performance contexts' (Rios 2008, p. 150), from the model it is supposed to come from (namely rural indigenous music practices) as 'cultural outsiders [cosmopolitans] transform and resignify non-cosmopolitan expressive practices to appeal to cosmopolitan audiences' (Rios 2008, p. 147). Considering modernist-capitalist cosmopolitanism as a specific 'culture', Rios (2008, 2012) argues that the development of Andean folkloric music results from intracultural exchanges and encounters (and not intercultural, as the protagonists do not have direct contact with the rural indigenous people). Therefore, in this case, transnational flows are also framed by the 'culture' lens.

Is Otavalo music, consequently, part of this cultural formation? Indeed, according to Rios (2012, pp. 14-15), Otavalos are 'more cosmopolitan', 'less egalitarian' and 'less communitarian' than indigenous people from Bolivia and southern Peru. However, I argue that the notion of cosmopolitanism, which appears as quite a closed 'culture' (even if it is not spatially bounded), is not relevant for the Otavalo case. While most Otavalos, with their diverse experiences of migration and the common accessibility of media and technology, may be (loosely) qualified as rather cosmopolitan, they are not disconnected from their region of origin: they usually refer to it as their homeland, they have developed quite a strong sense of identification to it, as most migrants return there regularly, for example (see Colloredo-Mansfeld 1999; Meisch 2002).

More interestingly for my argument, the participatory music played in the 1960s at local festivities initially influenced the first formal bands (see Schechter 1998; Meisch 2002) and, secondly, presentational and participatory music has continued to influence each other to date. On one hand, the 'traditional' music of San Juan festival, still played as a participatory performance in which everybody is welcome to play and dance, is the result of transnational exchanges. Indeed, amateur San Juan musicians have played the quena, zampoñas and charango (see Wibbelsman 2005, p. 198) since the 1980s, when Bolivian and Peruvian groups came to Otavalo to perform and when Otavalos began to migrate increasingly to Europe and North America. Additionally, current successful tunes released by indigenous groups following the Andean conjunto model may be played during San Juan festival visits to private houses, which involves an adaptation to this particular context, namely playing the tune repeatedly for 10 minutes or more, most likely out of tune (as the music is mostly played by amateur musicians, who continuously drink alcohol and play all night long, often over several nights). On the other hand, formal bands, through rigorous research into the local music of the past (interviewing elderly people, for example), may perform tunes closer to what was played locally in the 1960s, however adapting them, at the same time, to stage and recording formats. 
Consequently, Otavalos are neither part of a 'cosmopolitan culture' separated from an 'indigenous culture', nor are they refraining from participating in the circulation of flows of people, ideas, sounds and objects. In the Otavalo case, it is not possible to separate 'two cultures', one promoting participatory performance according to egalitarian and collective values and the other generating presentational music from hierarchical and individualist values.

Therefore, is Otavalo musical performance a question of 'postmodern pastiche', as Meisch apprehends its evolution? As in the case of the performance of Nanda Mañachi in Quito and in others as well, there is coherence for most of the people involved, for performers as much as for listeners/spectators (be they from Otavalo, Quito or abroad). The first step towards grasping this coherence is to consider Otavalo traditional music as a 'music world'.

\section{The network of people as a 'music world'}

Based on my discussion of Nanda Mañachi and the development of Otavalo music, traditional music appeared to emerge from and to be shaped by many flows crossing Otavalo, stemming from and heading towards different parts of the world (some from/to quite nearby, others from/to far away). The people, objects, ideas and sounds that I highlighted constitute a 'network' and circulate through 'lines' that connect 'nodes' where situations take place (see Latour 2005; Mueller 2016). The idea of the network allows us to go beyond the compartmentalisation of the notion of 'culture' and/or bounded places. Indeed, the interconnected social actors of the Otavalo case should not be apprehended through the precedence of their ethnicity/nationality, as the 'culture' lens tends to do. The connectivity between them seeks to allow tunes and musical styles to emerge that evoke 'tradition' in a place, a meaning which is however neither predetermined nor given. Every engaged social actor contributes in his/her own way to the construction and emergence of the idea and the sonic materiality of what is called 'traditional music', as well as 'Andean music'.

I argue that these interconnected social actors are part of what Becker (1982) calls an 'art world', that is 'the network of people whose cooperative activity, organized via their joint knowledge of conventional means of doing things, produces the kind of art works that art world is noted for' (Becker 1982, p. x). This concept focuses on human social actors, whereas the Latourian network and assemblage notions are wider, taking into account non-human entities. In this section, I am particularly interested in people (I will broaden my scope below). Crossley and Bottero $(2015$, p. 6) use 'music worlds' to refer to an art world in which music is at the core. ${ }^{15}$ Scholars who employ this notion do not consider it to be a closed entity: it is possible to go in and out, to connect and disconnect, so that the borders are blurred. I would add that a music world is situational and not based on origins, kinship and descent (even if these elements may have a relative impact according to the world in question): it emerges and is relevant in particular situations (for example, in live music performances, in recording sessions, in moments of listening to recorded music).

Becker (1982) insists on the cooperative dimension of the roles and actions of the different kinds of actors. For example, many people helped to create and to

15 Crossley and Bottero (2015) mention that other scholars use different terms, including 'scene', 'field' or 'network', to convey a conceptually equivalent meaning. 
make what Nanda Mañachi has become and means nowadays: without the combination of the French musicologist's initiative, the skilled musicians, the engineers who recorded their albums and a local, national and foreign public able to appreciate their tunes and to recognise them as 'traditional' and/or 'Andean', the group would not exist or would have been somehow different.

A 'world' is characterised by particular activities and issues, as well by people with central roles. In music worlds, one such role is that of 'musician', which consists of people who have constructed themselves as experts in an area of intellectual and practical knowledge. For musicians, the recognition of their role is at stake. It allows them to connect with other musicians from different backgrounds (and with translocal instruments and styles, for example) and with social actors involved in the world (like producers), as their role shapes these relations. ${ }^{16}$ They may also situationally regroup themselves as 'musicians' to differentiate themselves from others. In this sense, as this role needs to be learnt (including the intellectual and practical knowledge related to it), a musician's ethnicity is not necessarily relevant to competent performance (although an indigenous man growing up in Otavalo would have more opportunities to acquire this kind of knowledge). That is the reason why Italian people, for example, or the Bolivian mestizo, Japanese and US people in Bigenho's research $(2002,2012)$, can master the performance of Andean music. The role of musician is, therefore, not place-bounded.

Bigenho (2002) likewise highlights the importance of the role of musician for the members of the two mestizo groups who participated in her research. They selfidentified as 'musicians', as specialists of a specific activity which includes particular practices, such as rehearsals and paid performances (Bigenho 2002, pp. 99, 103-4). In her study of Bolivian mestizo and Japanese musicians playing Andean music (including herself as a US musician), Bigenho (2012) examines the relationships between them - as different nationals - and between them and the music - which is perceived by the musicians and Bigenho as 'other' because of its indigenous connotations. She understands these relationships as 'intimate distance': that is, a sense of intimacy with and desire for 'otherness', an affective identification with each other, while 'maintain[ing] the conceptual tension of those experiences through which one feels like and unlike others' (2012, p. 25). However, in both of Bigenho's studies (2002, 2012), ethnic and/or national origins seem to take precedence over other relevant categories (such as 'musician').

As Turino (1993, 2008) and Rios (2008, 2012), for example, distinguish the music performed in rural indigenous communities from the derived presentational styles in terms of difference of 'cultures', I propose to understand the differences in performance and sound through a pragmatist perspective. Namely, the differences emerge according to what is at stake and according to the relevant statuses and roles. Indeed, it is not the same, on the one hand, to play on stage in front of an audience who probably paid to watch a show and, on the other, to play music among a group of friends and/or relatives in the main square or for a very small audience in a private house, as is the case in different indigenous festivities in the Andes of southern Peru (see Turino 1993), of Bolivia (see Bigenho 2002) and in the San Juan fiesta in Otavalo (see Wibbelsman 2005; Voirol 2013). In the latter cases, the issue may be to compete

${ }^{16}$ As in other parts of the world, Otavalo musicians have used digital possibilities to intensify their connectivity. 
against another group of amateur musicians from a neighbouring community, by having more people and being noisier (see e.g. Turino 1993; Voirol 2013). In the former case, the issue may be to convey a sense of 'tradition', referring to an exotic otherness for foreign listeners, participating in the multicultural nation for non-indigenous national listeners, or a sense of 'tradition' with which indigenous people may identify. Any audiences have expectations that the performers seek to satisfy (to a certain extent at least), by demonstrating an adequate level of quality, in part because of economic issues (see Bigenho 2002, 2012).

\section{Traditional music as a process of production of indigeneity and place}

Both Nanda Mañachi and Trencito de los Andes are part of the same music world, which is not bounded by place. While the description and conceptualisation of traditional music in Otavalo in these terms reveal it to be a 'transnational project' (see Wade 2000, 2005; Dorr 2018), there are people who consider this music genre to be 'traditional'. Indeed, they work to give it a material and conceptual sense of 'tradition', which implies a bond to a particular place. This relation has to be constructed, produced and maintained through processes of traditionalisation, indigenisation and localisation; namely, processes that make a practice 'traditional', 'indigenous' and 'local'. These processes are at stake for the people involved in the music world of Otavalo traditional music (bands, producers, publics, among others): they may be related to the demand for exoticism by non-indigenous people and/or participation in the shaping of an 'own tradition' with which local indigenous people can identify (a relatively 'new' issue, mainly from the 1970s). Therefore, the question is what is, or is not, 'local', 'traditional', 'indigenous' for whom, when, why and how. This perspective draws its inspiration from Ochoa Gautier's 'localization' (2006) and Çalışkan and Callon's 'economization' approaches (2009). ${ }^{17}$

Ochoa Gautier (2006) uses 'localization' to analyse the nation-building projects of the first half of the 20th century in Latin America. White-mestizo folklorists and musicians aimed to valorise local sounds for nationalist purposes by adapting them for the urban elites, while seeking to invisibilise the connections to and their impact on indigenous music. This was done in order to convey an image of purity and to localise this music in bounded and remote places (Ochoa Gautier 2006; see also the work of Bigenho 2002; Dorr 2018). In a similar fashion, Wade (2008, pp. 43, 45-6) highlights a double move in the process of 'musical nationalism' in Latin America. Since the early 20th century, such musical nationalism has constituted the national elite appropriation (often marked by a 'cleaning up') of musical elements and styles from rural or lower-class populations in order to transform them into proper national music. However, these national music genres were also shaped by 'musical transnationalism', namely the circulation and influences of styles from different countries, which needed to be invisibilised to convey a national specificity.

Resulting from negotiations and contestations, these processes of localisation seek to create and produce an association between sound, people, and place, which may refer to a small place, a region, a nation or even beyond (like 'Latin America', Dorr 2018; see also Gupta \& Ferguson 1992; Luvaas 2009). 'What should

17 Çalışkan and Callon $(2009$, p. 370) refer to the processes of constituting a practice, a behaviour, an idea, an institution, among others, as 'economic'. 
traditions related to specific places sound like?' is the question that is at stake. For example, although it is a result of an assemblage of heterogeneous elements (whitemestizo composer, classical and indigenous musical influences, international musicians, etc.), the internationally famous tune 'El Cóndor pasa' sounds indigenous and/or Peruvian to national and international audiences, producing a deterministic link between (indigenous) people, 'culture' (music) and place (the Andes) (see Dorr 2018). To argue that El Cóndor pasa is not very 'typical' (Rios 2008, p. 160) may be musicologically correct; however it does not say anything about how musicians and publics apprehend it (obviously, musicology may shape what nonmusicologists think, but the opposite can also be true).

In a similar way, in the case of Otavalo, traditional music like that of Nanda Mañachi and of Trencito de los Andes likewise sounds indigenous - and/or Otavalan, Andean, Ecuadorian - to indigenous as much as to non-indigenous people (who may even listen to it as Peruvian or Bolivian). However, to grasp its complexity, we must understand the expression 'traditional music' as a label, and not as an essence of any kind: that is, as something that has to be filled with meaning, used through ascription and materialised. Therefore, we must understand the work of the social actors involved in making a form of music 'traditional' through the cutting of some connections in the network (see Latour 2005, p. 227; Hennion 2015; Mueller 2016) and through the assemblage of elements so that they can rely on each other to convey this sense of place and tradition.

\section{Assembling indigeneity through music}

The notion of assemblage is widely used in different ways in the social sciences, and also by scholars looking at music phenomena such as Born (2011), Mueller (2016), Nowak (2016), Tucker (2016) and de Assis (2018). I understand assemblage as a combination of different (human and non-human, actual and virtual) elements participating in and shaping a particular situation (see Latour 2005; Mueller 2016; and for musical experimentation, de Assis 2018). Drawing on Hennion (1993, 2015) and Latour (2005), these elements constitute 'mediators', which affect and transform the assemblage as they 'mak[e] other mediators do things' (Latour 2005, p. 217, emphasis in the original). As Hennion (1993, p. 14, 2015, p. 118) argues in the case of music practices, mediators produce music (and place and people, in the case of traditional music in Otavalo), while relying on each other, although not in a linear way (see also Born 2011). An assemblage does not exist as a stable entity but must be deployed, and work is needed to stabilise it (Hennion 1993; Latour 2005; Mueller 2016). ${ }^{18}$

The terms localisation, traditionalisation and indigenisation emphasise the action of the processes ('-isation'): as Çalışkan and Callon (2009, p. 370) argue for the notion of 'economization', it implies that 'the economy [and in my case tradition, indigeneity and locality] is an achievement rather than a starting point or a pre-existing reality that can simply be revealed and acted upon'. Therefore, place, tradition, indigeneity are not given, and if they are not given, then they could be

18 My use of 'assemblage', consequently, differs from the more descriptive utilisation by Nowak (2016, chapter 4), who addresses it as a set of predetermined relevant categories shaping musical taste. 
otherwise, and different people may have different views on these concepts. ${ }^{19}$ The notion of assemblage allows me to grasp this fluidity (see de Assis 2018) as well as the controversies that may emerge from what is, or is not, recognised as tradition and indigeneity.

In order to convey the idea and the materiality of traditional music, an assemblage should produce and evoke a sense of place, situated in Otavalo and/or in the Andes. This place should have connotations of the countryside, remoteness, nonmodernity (or at least threatened by modernity); a place outside metropolitan cities; 'another place' for non-indigenous people or a place with which indigenous people can identify. This place should also evoke the idea of (geographical) origins (see Wade 2008 for Afro-Colombian music) and of ancient time.

Referring to the vignette at the beginning of this article, most of the instruments (particularly the flutes), the playing techniques, the melodies, as well as the hairstyle and clothes ${ }^{20}$ of the Nanda Mañachi performers constitute mediators that are combined and rely on each other to produce meaning and to materialise it. Their performance sonically and visually evokes indigeneity and traditional music linked to a place (Otavalo and/or the Andes) for an audience of Otavalo people, as well as white-mestizo and foreign spectators. Rios (2012, p. 9) rightly affirms that the cane flutes in particular transmit a native image, and Bigenho (2002, p. 96) notes the strength of the visual aspect of the performance in conveying indigenous 'authenticity' for an (inter)national public, especially when the musicians (mestizos in her case) wear indigenous clothes. The use of microphones, an electric guitar and sound amplification for each instrument (which may evoke a sense of modernity, rather than tradition) is relegated to the background. The facts that the rondador, the cane panpipe emblematic of Otavalo indigenous people, has a native and European origin (Parra Pérez 2018), and that the musicians played several pieces arranged by a French musicologist, are made invisible. Therefore, the performance of traditional music focuses on some specific connections and makes some others invisible in order to allow its meaning to emerge and develop (processes of traditionalisation, indigenisation and localisation). However, the assemblage is made up of the connections between all of these elements and needs them all to work (see Hennion 1993).

The conceptualisation through the notion of assemblage also allows me to highlight controversies, such as when an assemblage does not work or works only partially or situationally. ${ }^{21}$ Namely, in my case study, I refer to controversies surrounding the processes of traditionalisation, indigenisation and localisation, which may question the limits of traditional/indigenous music, and the extent of its boundaries. This aspect is usually difficult to identify in many Andeanist studies: it is often implied that what is indigenous (or not) is quite obvious, through external observation (but cf. Tucker 2013). I argue that the conception in terms of 'cultures', even from a constructivist point of view, has the effect of dissimulating debates and disagreements within a group of people, which are part of everyday life.

19 Therefore, this perspective differs from the 'invented tradition' stance (Hobsbawm 1983), for which 'tradition' is a 'pre-existing reality', and which relies on scholars' definition of what is or not 'tradition'.

${ }^{20}$ Hairstyle and clothes play an important role in the self- and exo-identification of Otavalos; most indigenous people wear identifiable clothes (during special events for men, and on a more everyday basis for women) and most men wear long, braided hair.

21 On the contrary, Tucker (2016) insists on the potential of the stabilisation of indigeneity through a material assemblage (an instrument in his case). 
The case of Leo Rojas is relevant in this sense. He is a young man from an indigenous community in the Otavalo region who migrated to Germany several years ago. In 2011, he participated in a German televised musical contest. ${ }^{22}$ As part of his performance, he played the Peruvian tune El Cóndor pasa on Peruvian and Bolivian Andean flutes, with a New Age musical background and wearing clothes inspired by the Indians of North America (in several YouTube videos, he is labelled as 'the last Mohican'). He enjoyed a great deal of success and won the contest. The way that he assembled the elements of his performance conveyed Andean (or a vague) indigeneity and its traditions for most of the German viewers, which was an important part of his success. However, I heard many criticisms from most of my Otavalo indigenous interlocutors, who did not identify themselves with the image conveyed by Leo Rojas. Indeed, the combination of New Age and North American Indian elements tends to be rejected in building a sense of indigeneity and tradition, because it evokes another place for Otavalo people. For most of them, Rojas's performance evokes neither their indigeneity nor their tradition.

However, it could be different. It is true that the idea of 'Abya-Yala' (an indigeneity including all of the indigenous peoples of the Americas), promoted by some indigenous and white-mestizo intellectuals, is little known to common people in Otavalo. Nevertheless, there are situations in which a connection and an affective association are established by some Otavalos at least. Indeed, those who consider that native peoples from North America experienced a similar process of colonisation and of resistance may perceive them as 'indigenous' ('runa') like themselves. The invitation of Robert Mirabal, a native musician from Taos Pueblo, New Mexico, USA, to two musical events (in 2009 and 2012) organised by Otavalo people, with the aim of revalorising indigenous music, was thought of in those terms. At these two events, before an audience of several thousand people (mainly local indigenous people), he played his pieces inspired by Taos Pueblo music after Otavalo bands performed on the same stage. Other kinds of connections may be made; some Otavalo craftspeople produce dreamcatchers (based on those of North American natives), which are sold by Otavalo merchants along with other artefacts (mostly woven items). Additionally, Meisch (2002, pp. 175-7) shows how in the 1990s several Otavalo groups used the visual association with North American Indians on their album sleeves (mainly discs produced in Europe). Although she interprets this as a commercial issue and a 'cultural confusion' which seeks to resonate with European stereotypes on indigenous people, she also describes the member of the band Charijayac who appeared on an album sleeve, released in 1992, looking like a native of the Great Plains. He told her that this image evokes a warrior and that the band wanted to signify the resistance to the Columbus Quincentenary (Meisch 2002, p. 176).

This shows that place, tradition and indigeneity have to be produced and materialised, and that this constitutes a creative process. It is true that few Otavalo people considered Rojas's performance as representative of themselves, although some were proud of him for having won a contest in Europe. On the contrary, a band that uses a charango or a quena may still convey the idea of traditional music in Otavalo, despite the fact that both instruments arrived in the Otavalo region in the 1980s through

22 I have never met him personally, but I watched videos of his performances as part of this German show with some of my interlocutors. Many indigenous people in Otavalo also talked about him when he won this competition and became famous in the region. 
visits from Bolivian groups. Both are associated with the Andes and Otavalo people situationally conceive of themselves as 'Andean' (see Figures 2 and 3). Thus, Nanda Mañachi playing Bolivia Manta's pieces conveys the idea of 'own traditional' music. In these cases, the assemblage works, but it does not mean that it would work forever or in any situation.

The dynamism of the notion of assemblage, which resonates with the dynamism of everyday life, allows us to move beyond Meisch's idea of 'postmodern pastiche' (2002, p. 189), which gives the image of a non-controlled and senseless mixture. The notion helps us to understand the meanings that people give to it, the work undertaken to materialise it, and the controversies in which they are involved, taking into account what is at stake.

\section{Concluding remarks}

My ethnographic account has demonstrated how specific the musical practices of Otavalo indigenous people are, compared with those of other Andean indigenous populations. While it may constitute a more widespread stance in studies of popular musics, the conceptualisation of traditional music through the notions of 'network' and 'music world' allowed me to highlight the density of flows - of people, objects, ideas, sounds - that have shaped it. The link between a specific people, music and place is, therefore, unsettled and must be produced, as Dorr (2018) argues. In the anthropology of music, it has been easier to think of the non-predetermined dimension of this link when global styles are reappropriated in a different place from where they emerged, like pop music in Indonesia (Luvaas 2009), hip-hop in Senegal (Appert 2016) or hardcore in Japan (Mueller 2016). It seems to be more difficult to deal with it concerning 'traditional music', which is mostly apprehended as a 'music in place' in South America: namely, the emphasis on its 'ostensible aesthetic invariability and

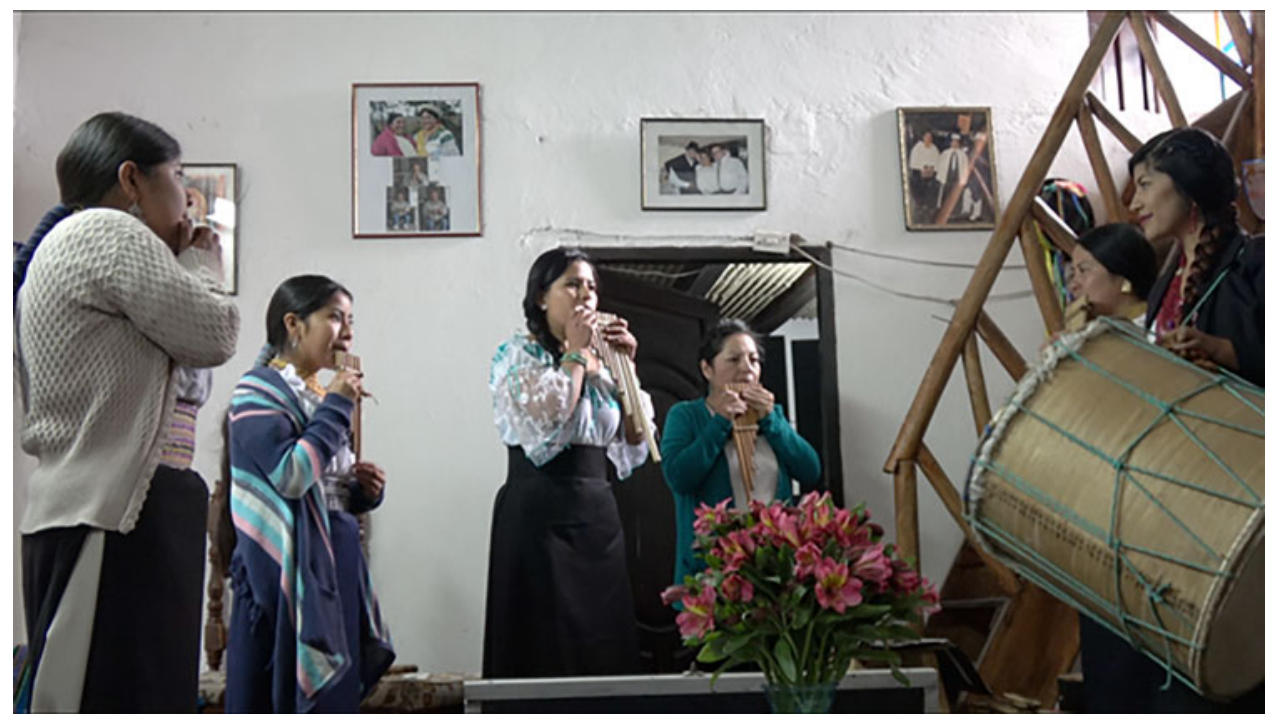

Figure 2. Band Waminsi playing a sikureada (Bolivian mestizo genre) in a rehearsal. 


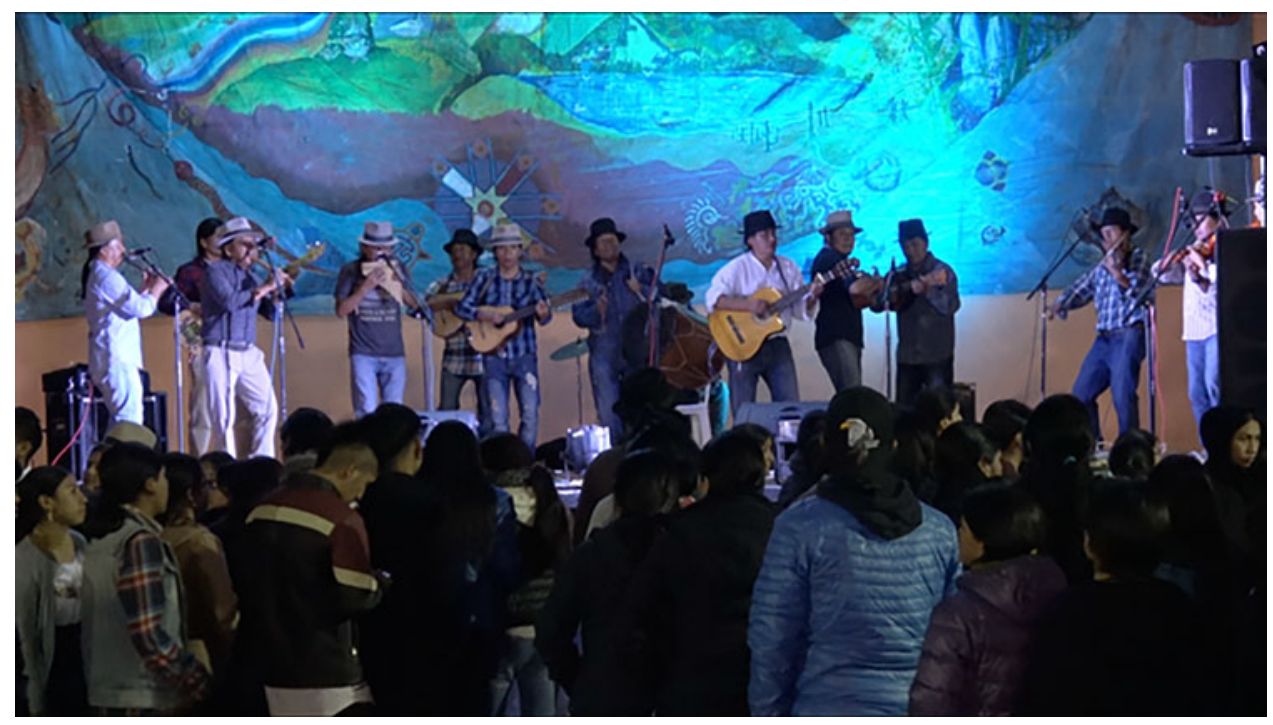

Figure 3. Band Mana Maymanda playing a sanjuanito with quenas, zampoña, bandolines, bombo, violin, guitar, bass guitar and drum, in an Otavalo indigenous community.

geographic autochthony' and its 'rootedness and continuity' (Dorr 2018, pp. 4-5; for a general tendency, see Appert 2016). Indeed, Rios (2008) and Turino (2008) recognise the transnational constitution of Andean conjuntos and how they must convey a sense of 'tradition' for (inter)national audiences: however, these scholars consider them as a 'misrepresentation' and/or an 'alteration' of traditional indigenous music. Bigenho (2002, pp. 21, 137) discusses 'decontextualization', implying a place of origin of indigenous music, namely the rural communities. As I have argued, this resonates with a conceptualisation from a 'culture' lens perspective.

Rather than mobilising decontextualisation, I have emphasised the processes of traditionalisation, indigenisation and localisation. The notion of assemblage has helped me to grasp these processes. Indeed, it has shown that indigenous traditional music must be produced: it is not a given and, consequently, controversies and negotiations about indigeneity and tradition may emerge in different situations. Assemblage has allowed me, therefore, to understand how human and non-human elements (sound, instruments, clothes, ideas and discourses, for example in my ethnographic study) combine and rely on each other to produce (or not) tradition, place and/or indigeneity. Traditional music is the effect of an assemblage, and not its cause (see Hennion 1993, p. 29).

\section{Acknowledgements}

I warmly thank my research participants for their collaboration, and Peter Wade and Guilherme Fians for their insightful comments on various versions of this article. Some of its key arguments also benefitted from inspiring remarks by Andrew Irving and Lorenzo Ferrarini, to whom I am grateful. I am also thankful to the two anonymous reviewers for their useful comments and suggestions and to the 
Swiss National Science Foundation, which funded the postdoctoral project within which I developed this article.

\section{References}

Appert, C. 2016. 'On hybridity in African popular music: the case of Senegalese hip hop', Ethnomusicology, 60/2, pp. 279-99

Becker, H. 1982. Art Worlds (Berkeley, CA, University of California)

Bigenho, M. 2002. Sounding Indigenous. Authenticity in Bolivian Music Performance (New York, Palgrave Macmillan)

Bigenho, M. 2012. Intimate Distance. Andean Music in Japan (Durham, NC, Duke University)

Born, G. 2011. 'Music and the materialization of identities', Journal of Material Culture, 16/4, pp. 376-88

Çalışkan, K., and M. Callon. 2009. 'Economization, part 1: shifting attention from the economy towards processes of economization', Economy and Society, 38/3, pp. 369-98

Canessa, A. 2006. 'Todos somos indígenas: Towards a new language of national political identity', Bulletin of Latin American Research, 25/2, pp. 241-63

Cervone, E. 2012. Long Live Atahualpa. Indigenous Politics, Justice, and Democracy in the Northern Andes (Durham, NC, Duke University)

Colloredo-Mansfeld, R. 1999. The Native Leisure Class. Consumption and Cultural Creativity in the Andes (Chicago, IL, University of Chicago)

Crossley, N., and W. Bottero. 2015. 'Social spaces of music: Introduction', Cultural Sociology, 9/1, pp. 3-19

de Assis, P. 2018. Logic of Experimentation (Leuven, Leuven University)

De la Cadena, M. 2000. Indigenous Mestizos. The Politics of Race and Culture in Cuzco, Peru, 1919-1991 (Durham, NC, Duke University)

Dorr, K. 2018. On Site, In Sound. Performance Geographies in América Latina (Durham, NC, Duke University)

Erlmann, V. 1996. 'The aesthetics of the global imagination: reflections on World Music in the 1990s', Public Culture, 8, pp. 467-87

Feld, S. 2004. 'Une si douce berceuse pour la "World Music"', L'Homme, 171-2, pp. 389-408

Gupta, A., and J. Ferguson. 1992. 'Beyond "culture": space, identity, and the politics of difference', Cultural Anthropology, 7/1, pp. 6-23

Hennion, A. 1993. 'L'histoire de l'art: leçons sur la médiation', Réseaux, 11, pp. 9-38

Hennion, A. 2015. 'La médiation: un métier, un slogan ou bien une autre définition de la politique?', Informations sociales, 190/4, pp. 116-23

Hobsbawm, E. 1983. 'Introduction: Inventing Traditions', in The Invention of Tradition, ed. E. Hobsbawm and T. Ranger (Cambridge, Cambridge University), pp. 1-14

Huarcaya, S.M. 2014. 'Imagining Ecuadorians. Historicizing national identity in twentieth-century Otavalo, Ecuador', Latin American Research Review, 49/3, pp. 64-84

Latour, B. 2005. Re-assembling the Social. An Introduction to Actor-network Theory (Oxford, Oxford University)

Luvaas, B. 2009. 'Dislocating sounds: the deterritorialization of Indonesian indie pop', Cultural Anthropology, 24/2, pp. 246-79

Meisch, L. 2002. Andean Entrepreneurs. Otavalo Merchants $\mathcal{E}$ Musicians in the Global Arena (Austin, TX, University of Texas)

Mendoza, Z. 2008. Creating Our Own. Folklore, Performance, and Identity in Cuzco, Peru (Durham, NC, Duke University)

Mueller, A. 2016. 'Beyond ethnographic scriptocentrism: Modelling multi-scalar processes, networks, and relationships', Anthropological Theory, 16/1, pp. 98-130

Nowak, R. 2016. Consuming Music in the Digital Age (Basingstoke, Palgrave Macmillan)

Ochoa Gautier, A.M. 2006. 'Sonic transculturation, epistemologies of purification and the aural public sphere in Latin America', Social Identities, 12/6, pp. 803-25

Pallares, A. 2002. From Peasant Struggles to Indian Resistance. The Ecuadorian Andes in the Late Twentieth Century (Norman, OK, University of Oklahoma)

Parra Pérez, H.H. 2018. 'Una gaita que ahora es pingullo: las resignificaciones del acervo musical hispánico colonial en lo indígena y lo campesino', presentation at the 56th International Congress of Americanists (Salamanca)

Rios, F. 2008. 'La Flûte Indienne: the early history of Andean folkloric-popular music in France and its impact on Nueva Canción', Latin American Music Review, 29/2, pp. 145-89

Rios, F. 2012. 'The Andean conjunto, Bolivian sikureada and the folkloric musical representation continuum', Ethnomusicology Forum, 21/1, pp. 5-29

Rivera Andía, J.J. 2018. 'Andean musical expressions. Ethnographic notes on materialities, ontologies, and alterities, in The Andean World, ed. L. Seligmann and K. Fine-Dare (New York, Routledge), pp. 452-67

Schechter, J. 1998. 'Ecuador', in The Garland Encyclopedia of World Music. Volume 2, ed. D. Olsen and D. Sheehy (New York, Garland), pp. 413-33

Starn, O. 1994. 'Rethinking the politics of anthropology: the case of the Andes', Current Anthropology, 35/1, pp. 13-38 
Stobart, H. 2006. Music and the Poetics of Production in the Bolivian Andes (Aldershot, Ashgate)

Stobart, H. 2008. 'In touch with the Earth? Musical instruments, gender and fertility in the Bolivian Andes', Ethnomusicology Forum, 17/1, pp. 67-94

Stobart, H. 2011. 'Constructing community in the digital home studio: carnival, creativity and indigenous music video production in the Bolivian Andes', Popular Music, 30/2, pp. 209-26

Stobart, H. 2017. 'Creative pragmatism: competency and aesthetics in Bolivian indigenous music video (VCD) production', in Music, Indigeneity, Digital Media, ed. T. Hilder, H. Stobart and S. Ee Tan (Rochester, NY, University of Rochester), pp. 127-55

Stokes, M. 2004. 'Music and the global order', Annual Review of Anthropology, 33, pp. 47-72

Tucker, J. 2013. 'Producing the Andean voice: Popular music, folkloric performance, and the possessive investment in indigeneity', Latin American Music Review, 34/1, pp. 31-70

Tucker, J. 2016. 'The machine of sonorous indigeneity: craftsmanship and sound ecology in an Andean instrument workshop', Ethnomusicology Forum, 25/3, pp. 326-44

Turino, T. 1993. Moving Away from Silence. Music of the Peruvian Altiplano and the Experience of Urban Migration (Chicago, IL, University of Chicago)

Turino, T. 1998. 'Quechua and Aymara', in The Garland Encyclopedia of World Music. Volume 2, ed. D. Olsen and D. Sheehy (New York, Garland), pp. 205-24

Turino, T. 2008. Music in the Andes. Experiencing Music, Expressing Culture (Oxford, Oxford University)

Voirol, J. 2013. 'Récit ethnographique d'une experience partagée de la fête de San Juan/Inti Raymi à Otavalo', Ethnologies, 35/1, pp. 51-74

Wade, P. 2000. Music, Race, and Nation. Música Tropical in Colombia (Chicago, IL, University of Chicago)

Wade, P. 2005. 'Nacionalismo musical en un contexto transnacional: la música popular costeña en Colombia', in Colombia y el Caribe/XIII Congreso de Colombianistas, ed. Universidad del Norte and Asociación de Colombianistas (w.p., Ediciones Uninorte), pp. 191-201

Wade, P. 2008. 'African diaspora and Colombian popular music in the twentieth century', Black Music Research Journal, 28/2, pp. 41-56

Wibbelsman, M. 2005. 'Encuentros: Dances of the Inti Raymi in Cotacachi, Ecuador', Latin American Music Review, 26/2, pp. 195-226

Wong Cruz, K. 2012. La Música Nacional. Identidad, mestizaje y migración en el Ecuador (La Habana, Casa de las Américas) 